\title{
Akrylonitryl
}

\section{Metoda oznaczania w powietrzu na stanowiskach pracy ${ }^{1}$}

\author{
Acrylonitrile \\ Determination in workplace air
}

\author{
dr inż. ANNA JEŻEWSKA \\ https://orcid.org/0000-0002-8765-4079 \\ inż. AGNIESZKA WOŹNICA \\ https://orcid.org/0000-0001-5335-5970
}

Centralny Instytut Ochrony Pracy - Państwowy Instytut Badawczy

Central Institute for Labour Protection - National Research Institute, Warsaw, Poland

Numer CAS 107-13-1

\section{Streszczenie}

Akrylonitryl (AN) jest wysoce łatwopalną, bezbarwną cieczą o nieprzyjemnym zapachu. W przemyśle akrylonitryl jest stosowany głównie do produkcji poliakrylonitrylu (PAN) i jego kopolimerów. Akrylonitryl może powodować raka. Celem prac badawczych było opracowanie metody oznaczania akrylonitrylu w powietrzu na stanowiskach pracy, która umożliwi oznaczanie jego stężeń na poziomie $0,1 \mathrm{mg} / \mathrm{m}^{3}$. Metoda polega na: adsorpcji zawartych w badanym powietrzu par akrylonitrylu na węglu aktywnym, desorpcji roztworem acetonu w disiarczku węgla i analizie chromatograficznej otrzymanego roztworu. Badania wykonano z zastosowaniem chromatografu gazowego (GC) z detektorem płomieniowo-jonizacyjnym (FID) wyposażonym w kolumnę kapilarną DB-VRX (60 m × 0,25 mm, 1,4 $\mu \mathrm{m})$. Walidację metody przeprowadzono zgodnie z wymaganiami zawartymi w normie europejskiej PN-EN 482. Metoda umożliwia oznaczanie akrylonitrylu w powietrzu środowiska pracy w zakresie stężeń $0,1 \div 2 \mathrm{mg} / \mathrm{m}^{3}$. Metoda oznaczania akrylonitrylu została przedstawiona w postaci procedury analitycznej, którą zamieszczono w załączniku. Zakres tematyczny artykułu obejmuje zagadnienia zdrowia oraz bezpieczeństwa i higieny środowiska pracy będące przedmiotem badań z zakresu nauk o zdrowiu oraz inżynierii środowiska.

Słowa kluczowe: akrylonitryl, metoda analityczna, powietrze na stanowiskach pracy, nauki o zdrowiu, inżynieria środowiska.

\footnotetext{
Abstract

Acrylonitrile (AN) is highly flammable, colorless liquid with an unpleasant odor. Acrylonitrile is used in industry to produce polyacrylonitrile (PAN) and its copolymers. Acrylonitrile can cause cancer. The aim of this study was to develop a method for determining acrylonitrile in workplace air which will allow determination of its concentrations at the level of $0.1 \mathrm{mg} / \mathrm{m}^{3}$. The method was based on adsorption of acrylonitrile vapors on activated carbon, desorption with acetone solution in carbon disulfide and chromatographic analysis of the obtained solution. The study was performed using a gas chromatograph (GC) with a flame ionization detector (FID) equipped with a DB-VRX capillary column $(60 \mathrm{~m} \times 0.25 \mathrm{~mm}, 1.4 \mu \mathrm{m})$. The method was validated in accordance with the requirements of Standard No. EN 482 . The method allows the determination of acrylonitrile in workplace air at the concentration range from 0.1 to $2 \mathrm{mg} / \mathrm{m}^{3}$.

${ }^{1}$ Opracowano na podstawie wyników V etapu programu wieloletniego „Poprawa bezpieczeństwa i warunków pracy”, finansowanego w zakresie zadań służb państwowych ze środków Ministerstwa Rozwoju, Pracy i Technologii (zadanie nr 1.SP.03 pt.: „Opracowanie znowelizowanych metod oznaczania 9 szkodliwych substancji chemicznych w powietrzu na stanowiskach pracy do oceny narażenia zawodowego"). Koordynator programu: Centralny Instytut Ochrony Pracy - Państwowy Instytut Badawczy.
} 
The method for determining acrylonitrile has been recorded in the form of an analytical procedure (see Appendix). This article discusses the problems of occupational safety and health, which are covered by health sciences and environmental engineering.

Keywords: acrylonitrile, determination method, workplace air, health sciences, environmental engineering.

\section{WPROWADZENIE}

Akrylonitryl (AN) jest wysoce lotną, wrażliwą na światło cieczą, której pary tworzą $\mathrm{z}$ powietrzem mieszaninę wybuchową. Akrylonitryl jest bardzo reaktywny, ma skłonność do spontanicznej polimeryzacji. Polimeryzacja często przebiega w sposób wybuchowy i może być inicjowana przez: światło, zanieczyszczenia, metale, związki metali lub ciepło. Wybuchowo reaguje m.in. z: silnymi zasadami, bromem, chlorem, utleniaczami, kwasem siarkowym, maślanem metylu, azotanem srebra, miedzią i jej stopami. Akrylonitryl przechowuje się z dodatkiem takich inhibitorów polimeryzacji, jak: hydrochinon, fenole lub woda amoniakalna. Pary akrylonitrylu są cięższe od powietrza. Podczas spalania akrylonitrylu powstają toksyczne tlenki azotu. Akrylonitryl rozpuszcza się w wodzie i w większości rozpuszczalników organicznych (ChemPył 2021; GESTIS 2021; PubChem 2021).

Akrylonitryl na skalę przemysłową otrzymuje się w wyniku reakcji cyjanowodoru i acetylenu lub cyjanowodoru i tlenku etylenu, w obecności katalizatora. Akrylonitryl jest stosowany $\mathrm{w}$ przemyśle głównie do produkcji poliakrylonitrylu (PAN) i jego kopolimerów. Z poliakrylonitrylu są produkowane takie włókna syntetyczne, jak anilana czy sztuczny jedwab. Kopolimery akrylonitrylu są tworzywem termoplastycznym. Z akrylonitrylu wytwarza się poli(akrylonitryl-co-styren) (SAN) oraz żywicę ABS (akrylonitryl-butadien-styren) - tworzywo sztuczne o bardzo dobrych własnościach mechanicznych. ABS jest stosowany w przemyśle motoryzacyjnym do produkcji części samochodowych (nadkola, przyciski, kratownice w samochodach). ABS jest również wykorzystywany do produkcji: sprzętu sportowego, części mebli, obudów sprzętu RTV/AGD i urządzeń elektronicznych, zabawek, części sprzętu biurowego, rur termoplastycznych (odpornych na agresywne ciecze) oraz wielu produktów codziennego użytku (IARC 1999; PubChem 2021). Akrylonitryl jest produkowany w Europejskim Obszarze Gospodarczym i/lub przywożony do niego w ilości od $\geq 1000000$ do $<10000000$ ton rocznie (ECHA 2021).
Akrylonitryl to substancja toksyczna, prawdopodobnie wskutek uwalniania w ustroju jonu cyjanowego działa dusząco, powodując niedotlenienie tkanek i zaburzenia ze strony ośrodkowego układu nerwowego, krążenia i oddychania. Działa drażniąco i uczulająco oraz rakotwórczo. Po okresie ok. 20 lat latencji prawdopodobnie mogą wystąpić nowotwory płuc i mózgu (ChemPył 2021).

Badania prowadzone przez Koutros i in. (2019; 2020) wskazują na związek między narażeniem pracowników na akrylonitryl a rakiem płuc, jak również na możliwe zwiększone ryzyko zgonu z powodu raka pęcherza moczowego i zapalenia płuc.

W państwach Unii Europejskiej akrylonitryl sklasyfikowano jako substancję rakotwórczą kategorii zagrożenia 1B, toksyczną, uczulającą, drażniącą, łatwopalną i stwarzającą zagrożenie dla środowiska wodnego (kat. 1). Substancji tej przypisano następujące zwroty określające rodzaj zagrożenia (Rozporządzenie Komisji (UE)... 2018):

- H225: wysoce łatwopalna ciecz i pary.

- H350: może powodować raka.

- H331: działa toksycznie $\mathrm{w}$ następstwie wdychania.

- H311: działa toksycznie w kontakcie ze skórą.

- H301: działa toksycznie po połknięciu.

- H335: może powodować podrażnienie dróg oddechowych.

- H315: działa drażniąco na skórę.

- H318: powoduje poważne uszkodzenie oczu.

- H317: może powodować reakcję alergiczną skóry.

- H411: działa toksycznie na organizmy wodne, powodując długotrwałe skutki.

Obowiązująca w Polsce wartość normatywu higienicznego - najwyższego dopuszczalnego stężenia (NDS) dla akrylonitrylu w powietrzu na stanowiskach pracy wynosi $2 \mathrm{mg} / \mathrm{m}^{3}$, a najwyższego 
dopuszczalnego stężenia chwilowego (NDSCh) $10 \mathrm{mg} / \mathrm{m}^{3}$ (Rozporządzenie... 2018).

W 2020 r. Zespół Ekspertów ds. Czynników Chemicznych, działający przy Międzyresortowej Komisji do spraw Najwyższych Dopuszczalnych Stężeń i Natężeń Czynników Szkodliwych dla Zdrowia w Środowisku Pracy, zaproponował nowe wartości normatywów higienicznych dla akrylonitrylu: NDS $=1 \mathrm{mg} / \mathrm{m}^{3}, \mathrm{NDSCh}=3 \mathrm{mg} / \mathrm{m}^{3}$ (Konieczko 2020). Nowe wartości NDS i NDSCh dla akrylonitrylu zostały przedłożone ministrowi właściwemu do spraw pracy w celu ich wprowadzenia do rozporządzenia $\mathrm{w}$ załączniku $\mathrm{nr} 1$ w części A wykazu najwyższych dopuszczalnych stężeń i natężeń czynników szkodliwych dla zdrowia w środowisku pracy.

W Polsce do oznaczania zawartości akrylonitrylu $\mathrm{w}$ powietrzu na stanowiskach pracy stosowano normę polską PN-Z-04113-12:2005. Metoda ta polegała na: adsorpcji par akryloni- trylu na węglu aktywnym, desorpcji roztworem acetonu w disiarczku węgla i analizie otrzymanego roztworu metodą chromatografii gazowej z detektorem płomieniowo-jonizacyjnym (GC-FID). Zakres krzywej wzorcowej wynosi $0,25 \div 12 \mathrm{mg} / \mathrm{m}^{3}$ (Madej, Jeżewska 2000).

W artykule przedstawiono metodę oznaczania akrylonitrylu zawartego $\mathrm{w}$ powietrzu na stanowiskach pracy $\mathrm{w}$ celu nowelizacji normy PN-Z-04113-12:2005, aby umożliwić oznaczanie związku w zakresie stężeń od $1 / 10$ do 2 wartości NDS zaproponowanej przez Zespół Ekspertów ds. Czynników Chemicznych, czyli od $0,1 \mathrm{do} 2 \mathrm{mg} / \mathrm{m}^{3}$, zgodnie $\mathrm{z}$ wymaganiami zawartymi $\mathrm{w}$ normie europejskiej PN-EN 482.

Zakres tematyczny artykułu obejmuje zagadnienia zdrowia oraz bezpieczeństwa i higieny środowiska pracy będące przedmiotem badań z zakresu nauk o zdrowiu oraz inżynierii środowiska.

\section{CZĘŚĆ DOŚWIADCZALNA}

\section{Aparatura}

Do wykonania oznaczeń stosowano chromatograf gazowy firmy Hewlett-Packard 6890 (HP, Niemcy) $\mathrm{z}$ detektorem płomieniowo-jonizacyjnym oraz automatycznym podajnikiem próbek. Do sterowania procesem oznaczania i zbierania danych korzystano z oprogramowania ChemStation. W badaniu stosowano kolumnę kapilarną typu DB-VRX o wymiarach: $60 \mathrm{~m} \times 0,25 \mathrm{~mm}, 1,4 \mu \mathrm{m}$ (Agilent Technologies, USA).

Do pobierania próbek powietrza stosowano aspiratory typu Gilian FLS (Sensidyne, USA).

Do przeprowadzenia ekstrakcji analitów z sorbentów korzystano z wytrząsarki mechanicznej WL-2000 (JW Electronic, Polska). Wzorce odważano na wadze analitycznej Sartorius TE214S (Sartorius Corporation, USA). Próbki przechowywano w eksykatorze szafkowym serii EKS (WSL, Polska) i w zamrażalniku chłodziarki ARDO CO23B-2H (Merloni, Polska).

\section{Odczynniki i materiały}

W badaniach stosowano następujące odczynniki o czystości co najmniej cz.d.a.: akrylonitryl (Merck, Niemcy), aceton, disiarczek węgla (Sigma-Aldrich, Niemcy).

Ponadto stosowano: rurki szklane wypełnione węglem aktywnym (100 mg/50 mg, Zakład Usługowo-Produkcyjny „Analityk”, Polska), szkło laboratoryjne oraz strzykawki do cieczy.

\section{WYNIKI BADAŃ I ICH OMÓWIENIE}

\section{Ustalenie warunków oznaczania chromatograficznego}

$\mathrm{Na}$ podstawie danych literaturowych oraz badań wstępnych ustalono warunki oznaczania chromatograficznego akrylonitrylu. Zastosowano kolumnę kapilarną DB-VRX w temperaturze $40{ }^{\circ} \mathrm{C}$. Strumień objętości gazu nośnego (hel) ustalono na $1 \mathrm{ml} / \mathrm{min}$. Próbkę o objętości $2 \mu \mathrm{l}$ dozowano w temperaturze $160{ }^{\circ} \mathrm{C}$, stosunek dzielenia próbki ustalono na 10: 1 . Temperatura detektora FID wynosiła $180^{\circ} \mathrm{C}$, 


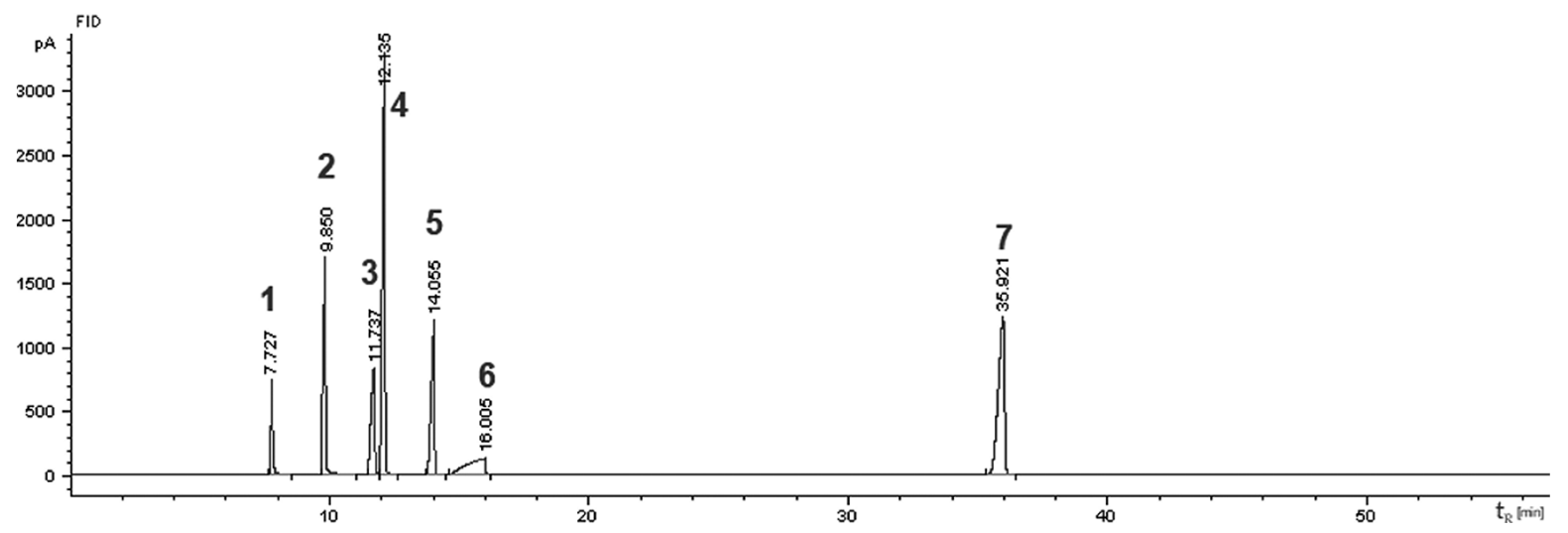

Ryc. 1. Chromatogram roztworu wzorcowego akrylonitrylu i substancji współwystępujących. Kolumna DB-VXR, temperatura kolumny $40{ }^{\circ} \mathrm{C}$, detektor FID.

Objaśnienia: 1) metanol, 2) etanol, 3) aceton, 4) akrylonitryl, 5) acetonitryl, 6) disiarczek węgla, 7) benzen

Fig. 1. Chromatogram of a standard solution of acrylonitrile and co-occurring substances. DB-VXR column, $40{ }^{\circ} \mathrm{C}$, FID detector.

Notes: 1) methanol, 2) ethanol, 3) acetone, 4) acrylonitrile, 5) acetonitrile, 6) carbon disulfide, 7) benzene

strumień objętości wodoru $45 \mathrm{ml} / \mathrm{min}$, a powietrza $450 \mathrm{ml} / \mathrm{min}$.

W opisanych warunkach sprawdzono możliwość oznaczania akrylonitrylu w obecności: disiarczku węgla, acetonu, metanolu, etanolu, acetonitrylu i benzenu (ryc. 1.).

\section{Ustalenie warunków pobierania próbek powietrza}

W metodzie przyjęto podobny sposób pobierania próbek powietrza do tego, jaki zastosowano w normie podlegającej nowelizacji. Próbki powietrza pobierano na rurki szklane wypełnione dwiema warstwami węgla aktywnego, ale zmniejszono pierwszą warstwę węgla aktywnego z 200 na 100 mg, natomiast zwiększono objętość powietrza przepuszczanego przez próbnik z 20 do 24 litrów. Sprawdzono, czy próbki powietrza zawierające akrylonitryl mogą być pobierane na rurki szklane wypełnione węglem aktywnym (100 mg/50 mg). W tym celu na włókno szklane znajdujące się w rurkach pochłaniających przed 100-miligramową warstwą węgla aktywnego, nanoszono po 5 i $10 \mu$ roztworu akrylonitrylu w mieszaninie acetonu i disiarczku węgla (2: 98, $v / v$ ) o stężeniu $24 \mathrm{mg} / \mathrm{ml}$ (stężenie akrylonitrylu w powietrzu odpowiadające 5 i 10 NDS). Przez rurki przepuszczano 21 powietrza ze stałym strumieniem objętości 8 l/h przez 15 minut (do oceny warunków pracy z NDSCh) i 241 powietrza ze stałym strumieniem objętości 4 l/h (do oceny warunków pracy z NDS). Roztwory uzyskane po desorpcji rozpuszczalnikiem (aceton w disiarczku węgla) z pierwszej i drugiej warstwy węgla aktywnego oznaczano chromatograficznie w warunkach opisanych wyżej. Wyniki badań przedstawiono w tabeli 1 .

Uzyskane wyniki wskazują, że akrylonitryl zatrzymuje się w pierwszej warstwie węgla aktywnego. W drugiej zabezpieczającej warstwie węgla stwierdzono obecność akrylonitrylu w ilości nieprzekraczającej $10 \% \mathrm{w}$ stosunku do warstwy pierwszej i tylko w pomiarach krótkoterminowych przy bardzo dużym stężeniu substancji w powietrzu $\left(10 \mathrm{mg} / \mathrm{m}^{3}\right)$. Przeprowadzone badania wykazały, że rurka pochłaniająca wypełniona węglem aktywnym w ilości 100/50 mg jest odpowiednim adsorbentem do pobierania akrylonitrylu z powietrza. Do desorpcji stosowano $1 \mathrm{ml}$ roztworu acetonu w disiarczku węgla, analogicznie jak w normie nowelizowanej. 
Tabela 1. Wyniki adsorpcji akrylonitrylu na węglu aktywnym. GC-FID, kolumna DB-VRX Table 1. Results of acrylonitrile adsorption on activated carbon. GC-FID, DB-VRX column

\begin{tabular}{|c|c|c|c|c|c|c|c|}
\hline \multirow{2}{*}{$\begin{array}{l}\text { Numer } \\
\text { rurki }\end{array}$} & \multirow{2}{*}{$\begin{array}{c}\text { Strumień objętości } \\
\text { pochłanianego } \\
\text { powietrza, } \\
\text { l/h }\end{array}$} & \multirow{2}{*}{$\begin{array}{l}\text { Czas pochłaniania, } \\
\text { min }\end{array}$} & \multirow{2}{*}{$\begin{array}{c}\text { Przyblizzone } \\
\text { stężenie } \\
\text { substancji } \\
\text { w powietrzu, } \\
\mathrm{mg} / \mathrm{m}^{3}\end{array}$} & \multicolumn{3}{|c|}{$\begin{array}{c}\text { Średnia powierzchnia pików akrylonitrylu } \\
\text { w roztworach po desorpcji }\end{array}$} & \multirow{2}{*}{$\begin{array}{c}\text { Zawartość substancji } \\
\text { osadzonej w II warstwie } \\
\text { węgla (w \% ilości oznaczonej } \\
\text { w I warstwie węgla) }\end{array}$} \\
\hline & & & & $\begin{array}{l}\text { włókno } \\
\text { szklane }\end{array}$ & $\begin{array}{l}\text { I warstwa } \\
\text { węgla }\end{array}$ & $\begin{array}{l}\text { Il warstwa } \\
\text { węgla }\end{array}$ & \\
\hline 1 & 8 & 15 & 5 & brak piku & 254,1 & 0 & 0,00 \\
\hline 2 & \multirow{5}{*}{8} & \multirow{5}{*}{15} & \multirow{2}{*}{5} & brak piku & 242,7 & 0 & 0,00 \\
\hline 3 & & & & brak piku & 226,1 & 0 & 0,00 \\
\hline 4 & & & \multirow{3}{*}{10} & brak piku & 484,9 & 17,5 & 3,61 \\
\hline 5 & & & & brak piku & 460,7 & 9,05 & 1,96 \\
\hline 6 & & & & brak piku & 393,9 & 2,75 & 0,70 \\
\hline 7 & \multirow{6}{*}{4} & \multirow{6}{*}{360} & \multirow{3}{*}{5} & brak piku & 236,8 & 0 & 0,00 \\
\hline 8 & & & & brak piku & 225,8 & 0 & 0,00 \\
\hline 9 & & & & brak piku & 228,5 & 0 & 0,00 \\
\hline 10 & & & \multirow{3}{*}{10} & brak piku & 465,8 & 0 & 0,00 \\
\hline 11 & & & & brak piku & 449,3 & 0 & 0,00 \\
\hline 12 & & & & brak piku & 459,8 & 0 & 0,00 \\
\hline
\end{tabular}

\section{Badanie stopnia desorpcji}

Badanie stopnia desorpcji akrylonitrylu $\mathrm{z}$ węgla aktywnego przeprowadzano $\mathrm{w}$ następujący sposób: do sześciu rurek pochłaniających na włókno szklane umieszczone przed 100-miligramową warstwą węgla aktywnego nanoszono $\mathrm{w}$ trakcie pobierania próbek powietrza po $5 \mu$ roztworu akrylonitrylu w rozpuszczalniku o stężeniu $4,8 \mathrm{mg} / \mathrm{ml}$, co odpowiadało $24 \mu \mathrm{g}$ akrylonitrylu. Do kolejnych sześciu rurek adsorpcyjnych dodano po $10 \mu \mathrm{l}$ tego samego roztworu akrylonitrylu, co odpowiadało $48 \mu \mathrm{g}$ akrylonitrylu, a do kolejnych sześciu rurek dodano po $10 \mu \mathrm{l}$ roztworu akrylonitrylu o stężeniu $0,24 \mathrm{mg} / \mathrm{ml}$, co odpowiadało
2,4 $\mu \mathrm{g}$ akrylonitrylu. Przez rurki przepuszczano 241 powietrza ze strumieniem objętości 4 l/h. Następnie przeprowadzono desorpcję akrylonitrylu z pierwszej warstwy węgla i z drugiej warstwy zabezpieczającej przy użyciu $1 \mathrm{ml}$ rozpuszczalnika (aceton w disiarczku węgla). Po 30-minutowym wytrząsaniu uzyskane roztwory oznaczano chromatograficznie. Drugie zabezpieczające warstwy węgla nie zawierały badanej substancji. Wykonano także oznaczanie akrylonitrylu w roztworach porównawczych wykonanych w identyczny sposób, ale bez węgla aktywnego. Średni współczynnik desorpcji dla trzech poziomów stężeń wynosi 0,97 . Wyniki badań przedstawiono w tabeli 2 .

Tabela 2. Badania stopnia desorpcji akrylonitrylu z węgla aktywnego. GC-FID, kolumna DB-VRX

Table 2. Studies on desorption rate of acrylonitrile from activated carbon. GC-FID, DB-VRX column

\begin{tabular}{|l|c|c|c|}
\hline $\begin{array}{l}\text { llość akrylonitrylu naniesiona } \\
\text { na węgiel, } \\
\mu \mathrm{g}\end{array}$ & $\begin{array}{c}\text { Średnia powierzchnia pików } \\
\text { z roztworów po desorpcji }\end{array}$ & $\begin{array}{c}\text { Średnia powierzchnia pików } \\
\text { z roztworów porównawczych }\end{array}$ & Średni współczynnik desorpcji \\
\hline 2,4 & 4,69 & 4,85 & 0,97 \\
\hline 24 & 45,68 & 48,05 & 0,95 \\
\hline 48 & 93,38 & 94,9 & 0,98 \\
\hline
\end{tabular}




\section{Kalibracja i precyzja}

Oznaczanie kalibracyjne wykonywano dla sześciu roztworów wzorcowych akrylonitrylu w rozpuszczalniku (aceton i disiarczek węgla, 2: 98, v/v). Zakres stężeń roztworów wzorcowych wynosi $2,4 \div 48 \mu \mathrm{g} / \mathrm{ml}$. Sporządzono trzy serie roztworów kalibracyjnych, które poddano analizie chromatograficznej. Do chromatografu wprowadzono po $2 \mu \mathrm{l}$ roztworów wzorcowych o wzrastających stężeniach. Następnie sporządzono wykres zależności średniej powierzchni pików akrylonitrylu od jego stężeń w roztworach wzorcowych (ryc. 2.). Współczynnik nachylenia $b$ krzywej kalibracji o równaniu $y=b x+a$, charakteryzujący czułość metody, wynosi 2,36. Liniowość krzywej wzorcowej charakteryzowana jest wartością współczynnika korelacji. Współczynnik korelacji $r$ wynosi 0,9999 .

W celu oceny precyzji oznaczeń kalibracyjnych przygotowano roztwór akrylonitrylu o stężeniu $0,24 \mathrm{mg} / \mathrm{ml}$. Wykonano $\mathrm{z}$ niego trzy serie po osiem roztworów roboczych przez odmierzenie do kolb miarowych o pojemności $1 \mathrm{ml}$ po: 10 (I seria); 100 (II seria) i $200 \mu \mathrm{l}$ (III seria) roztworu podstawowego i dopełnienie rozpuszczalnikiem do kreski; $1 \mathrm{ml}$ tak przygotowanych roztworów zawierał kolejno: 2,4; 24 i $48 \mu \mathrm{g}$ akrylonitrylu. Wykonano pomiary chromatograficzne. Na podstawie odczytanych powierzchni pików uzyskanych na chromatogramach obliczono odchylenie standardowe i współczynnik zmienności. Współczynniki zmienności dla kolejnych poziomów stężenia wynoszą odpowiednio: 3,73 ; 2,64 i $2,27 \%$.

\section{Badanie trwałości próbek}

Trwałość pobranych próbek powietrza badano po: 2 , 4 i 6 dniach przechowywania w zamrażalniku chłodziarki. Wyniki badań przedstawiono w tabeli 3 .

$\mathrm{Na}$ podstawie uzyskanych wyników stwierdzono, że próbki przechowywane w zamrażalniku chłodziarki są trwałe co najmniej 6 dni.

\section{Walidacja metody}

Walidację metody przeprowadzono według wytycznych zawartych w normie PN-EN 482. Granicę wykrywalności i granicę oznaczalności wyznaczono na podstawie wyników analiz (dziesięć niezależnych pomiarów powierzchni piku o czasie retencji AN) uzyskanych $\mathrm{z}$ trzech niezależnie przygotowanych ślepych prób.

Dane walidacyjne uzyskane na podstawie przeprowadzonych badań przedstawiono w tabeli 4 .

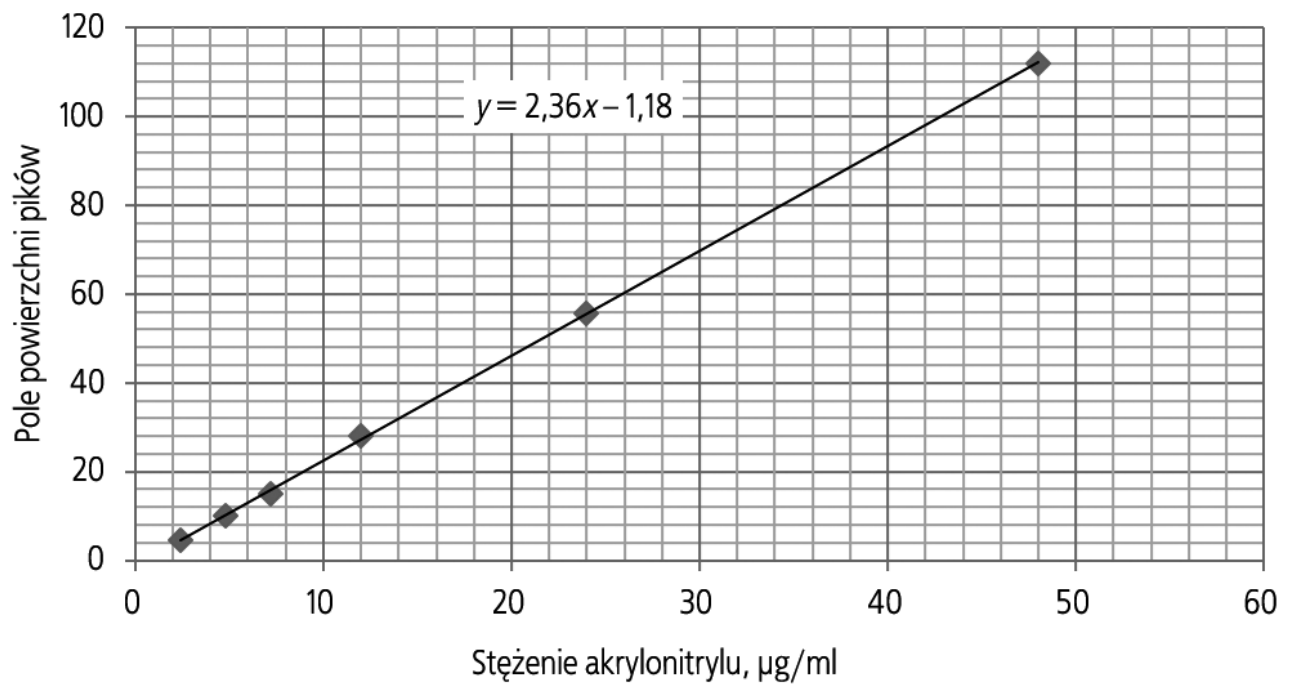

Ryc. 2. Wykres zależności powierzchni pików od stężenia akrylonitrylu w roztworach wzorcowych. GC-FID, kolumna DB-VRX Fig. 2. Plot of peak area dependence of acrylonitrile concentration in standard solution. GC-FID, DB-VRX column 
Tabela 3. Wyniki badania trwałości próbek powietrza zawierających akrylonitryl. GC-FID, kolumna DB-VRX Table 3. Results of a stability study of air samples containing acrylonitrile. GC-FID, DB-VRX column

\begin{tabular}{|l|c|c|c|c|}
\hline $\begin{array}{l}\text { Numer } \\
\text { rurki }\end{array}$ & $\begin{array}{c}\text { Czas przechowywania, } \\
\text { liczba dni }\end{array}$ & Średnie pola powierzchni pików & Średnia & Odchylenie standardowe \\
\hline 1 & 0 & 43,3 & 43,65 & 0,5 \\
\hline 2 & 44,0 & 44,30 & 0,1 \\
\hline 1 & 4 & 44,4 & 43,95 & 0,1 \\
\hline 2 & 4 & 44,2 & 4,9 & 0,1 \\
\hline 1 & 6 & 44,0 & 44,30 & \\
\hline 2 & 4 & 44,4 & \\
\hline 1 & 4 & 44,2 & \\
\hline
\end{tabular}

Tabela 4. Dane walidacyjne metody oznaczania akrylonitrylu

Table 4. Validation data of a method for acrylonitrile determination

\begin{tabular}{|l|c|}
\hline Walidowane parametry & Wartość \\
\hline Zakres pomiarowy & $0,1 \div 2 \mathrm{mg} / \mathrm{m}^{3}$ \\
llość pobranego powietrza & 241 \\
Zakres krzywej wzorcowej & $2,4 \div 48 \mu \mathrm{g} / \mathrm{ml}$ \\
Granica wykrywalności & $1,96 \mathrm{ng} / \mathrm{ml}$ \\
Granica oznaczalności & $5,87 \mathrm{ng} / \mathrm{ml}$ \\
Całkowita precyzja badania & $5,8 \%$ \\
Względna niepewność całkowita & $13 \%$ \\
Niepewność rozszerzona & $25 \%$ \\
\hline
\end{tabular}

\section{PODSUMOWANIE}

$\mathrm{W}$ artykule przedstawiono znowelizowaną metodę oznaczania akrylonitrylu $\mathrm{w}$ powietrzu na stanowiskach pracy. Metoda polega na: adsorpcji par akrylonitrylu na węglu aktywnym, desorpcji mieszaniną acetonu i disiarczku węgla oraz analizie otrzymanego roztworu $\mathrm{z}$ zastosowaniem chromatografu gazowego $\mathrm{z}$ detektorem płomieniowo-jonizacyjnym. Zastosowanie do analizy kolumny DB-VRX pozwoliło na selektywne oznaczenie akrylonitrylu w obecności: disiarczku węgla, acetonu i innych substancji współwystępujących w badanym powietrzu.
Opracowana metoda umożliwia oznaczanie akrylonitrylu w zakresie stężeń $0,1 \div 2 \mathrm{mg} / \mathrm{m}^{3}$, tj. od 1/10 do 2 wartości zaproponowanego najwyższego dopuszczalnego stężenia. W tym zakresie stężeń metoda została poddana walidacji zgodnie $\mathrm{z}$ wytycznymi zawartymi $\mathrm{w}$ normie PN-EN 482. Wyznaczono takie parametry walidacyjne, jak: granicę wykrywalności, granicę oznaczalności, całkowitą precyzję badania, względną niepewność całkowitą i niepewność rozszerzoną.

\section{PIŚMIENNICTWO}

ChemPył (2021). Baza wiedzy o zagrożeniach chemicznych i pyłowych [Knowledge base on chemical and dust hazards]. Warszawa, CIOP-PIB [https://www.ciop.pl/CIOPPortalWAR/ appmanager/ciop/pl?_nfpb=true\&_pageLabel=P2740017141410159698248].
ECHA (2021). Acrylonitrile. Registration dossier [https://echa. europa.eu/pl/registration-dossier/-/registered-dossier/15561].

GESTIS (2021). Substance database. BG Institute for Occupational Safety and Health, Sankt Augustin, Germany [https:// gestis-database.dguv.de/data? name $=011410]$. 
IARC (1999). Re-evaluation of some organic chemicals, hydrazine and hydrogen peroxide. IARC Monogr. Eval. Carc. Risk Chem. Man. Lyon, France, 71, 43-108.

Konieczko K. (2020). Akrylonitryl. Dokumentacja proponowanych dopuszczalnych wielkości narażenia zawodowego [Acrylonitrile. Documentation of proposed values of occupational exposure limits (OELs)]. Podst. Metod. Ocen. Środ. Pr. 4(106), 37-88.

Koutros S., Lubin J.H., Graubard B.I., Blair A., Beane Freeman L.E., Silverman D.T. (2020). Six authors reply. Am. J. Epidemiol. 189(4), 361-362.

Koutros S., Lubin J.H., Graubard B.I., Blair A., Stewart P.A., Beane Freeman L.E., Silverman D.T. (2019). Extended mortality follow-up of a cohort of 25,460 workers exposed to acrylonitrile. Am. J. Epidemiol. 188(8); 1484- 1492.

Madej M., Jeżewska A. (2000). Akrylonitryl - metoda oznaczania [Acrylonitrile - determination method]. Podst. Metod. Ocen. Środ. Pr. (25), 25-29.

PN-EN 482+A1:2016 Narażenie na stanowiskach pracy Wymagania ogólne dotyczące charakterystyki procedur pomiarów czynników chemicznych [Workplace exposure General requirements for the performance of procedures for the measurement of chemical agents].

PN-Z-04113-12:2005 Ochrona czystości powietrza. Badania zawartości związków akrylowych. Część 12: Oznaczanie akrylonitrylu na stanowiskach pracy metodą chromatografii gazowej [Air purity protection - Determination of acrylate compounds - Part 12: Determination of acrylonitrile at workplaces by gas chromatography].

PubChem (2021). Bethesda (MD): National Library of Medicine (US), National Center for Biotechnology Information; PubChem Compound Summary for CID 7855, Acrylonitrile [https://pubchem.ncbi.nlm.nih.gov/compound/Acrylonitrile].

Rozporządzenie Komisji (UE) 2018/669 z dnia 16 kwietnia 2018 r. zmieniające, w celu dostosowania do postępu naukowo-technicznego, rozporządzenie Parlamentu Europejskiego i Rady (WE) nr 1272/2008 w sprawie klasyfikacji, oznakowania i pakowania substancji i mieszanin. Dz. Urz. UE z dnia 4.05.2018 r. (L 115/1) [Commission Regulation (EU) 2018/669 of 16 April 2018 amending, for the purposes of its adaptation to technical and scientific progress, Regulation (EC) No 1272/2008 of the European Parliament and of the Council on classification, labelling and packaging of sub-stances and mixtures].

Rozporządzenie Ministra Rodziny, Pracy i Polityki Społecznej z dnia 12 czerwca 2018 r. w sprawie najwyższych dopuszczalnych stężeń i natężeń czynników szkodliwych dla zdrowia w środowisku pracy. DzU 2018, poz. 1286, ze zm. [Polish legal act]. 


\section{PROCEDURA ANALITYCZNA OZNACZANIA AKRYLONITRYLU W POWIETRZU NA STANOWISKACH PRACY}

\section{Zakres procedury}

W niniejszej procedurze podano metodę oznaczania akrylonitrylu (numer CAS: 107-13-1) w powietrzu na stanowiskach pracy $\mathrm{z}$ zastosowaniem chromatografu gazowego $\mathrm{z}$ detektorem płomieniowo-jonizacyjnym. Metodę stosuje się podczas kontroli warunków sanitarnohigienicznych.

Najmniejsze stężenie akrylonitrylu, jakie można oznaczyć w warunkach pobierania próbek powietrza i wykonania oznaczania opisanych $\mathrm{w}$ procedurze, wynosi $0,1 \mathrm{mg} / \mathrm{m}^{3}$ (dla próbki powietrza o objętości 24 1).

\section{Powołania normatywne}

PN-Z-04008-7 Ochrona czystości powietrza Pobieranie próbek - Zasady pobierania próbek powietrza w środowisku pracy i interpretacji wyników.

\section{Zasada metody}

Metoda polega na: adsorpcji zawartych w badanym powietrzu par akrylonitrylu na węglu aktywnym, desorpcji roztworem acetonu w disiarczku węgla i analizie chromatograficznej otrzymanego roztworu.

\section{Wytyczne ogólne}

\subsection{Dokładność ważenia}

O ile nie zaznaczono inaczej, substancje stosowane w analizie należy ważyć $\mathrm{z}$ dokładnością do $0,0002 \mathrm{~g}$.

4.2. Postępowanie $z$ substancjami niebezpiecznymi

Czynności, podczas których używa się rozpuszczalników organicznych, należy wykonywać z użyciem środków ochrony indywidualnej, pod sprawnie działającym wyciągiem laboratoryjnym. Pozostałe po analizie roztwory odczynników i wzorców należy gromadzić $\mathrm{w}$ przeznaczonych do tego celu pojemnikach i przekazywać do utylizacji w uprawnionych instytucjach.

\section{Odczynniki, roztwory i materiały}

Podczas analizy, o ile nie zaznaczono inaczej, należy stosować substancje o stopniu czystości co najmniej cz.d.a.

5.1. Akrylonitryl

5.2. Aceton

5.3. Disiarczek węgla

5.4. Roztwór acetonu w disiarczku węgla Stosować roztwór acetonu wg punktu 5.2. w disiarczku węgla wg punktu 5.3. w stosunku objętościowym 2: 98, $v / v$.

5.5. Roztwór wzorcowy podstawowy akrylonitrylu

Do zważonej kolby pomiarowej o pojemności $10 \mathrm{ml}$ odważyć około $240 \mathrm{mg}$ akrylonitrylu, kolbę zważyć, uzupełnić do kreski roztworem acetonu w disiarczku węgla wg punktu 5.4. i zawartość dokładnie wymieszać. Stężenie akrylonitrylu $\mathrm{w}$ tak przygotowanym roztworze wynosi około $24 \mathrm{mg} / \mathrm{ml}$. Obliczyć dokładne stężenie akrylonitrylu w roztworze.

5.6. Roztwór wzorcowy pośredni akrylonitrylu Do kolby pomiarowej o pojemności $10 \mathrm{ml}$ odmierzyć $100 \mu \mathrm{l}$ roztworu wzorcowego podstawowego wg punktu 5.5., uzupełnić do kreski roztworem acetonu w disiarczku węgla wg punktu 5.4. i zawartość dokładnie wymieszać. Stężenie akrylonitrylu $\mathrm{w}$ tak przygotowanym roztworze wynosi około $0,24 \mathrm{mg} / \mathrm{ml}$.

5.7. Roztwory wzorcowe robocze akrylonitrylu Do sześciu kolb pomiarowych o pojemności $1 \mathrm{ml}$ odmierzyć kolejno: 10; 20; 30; 50; 100 i $200 \mu \mathrm{l}$ roztworu wzorcowego pośredniego wg punktu 5.6., uzupełnić do kreski roztworem acetonu w disiarczku węgla wg punktu 5.4. i wymieszać. Zawartość akrylonitrylu $\mathrm{w} 1 \mathrm{ml}$ tak przygotowanych roztworów wynosi odpowiednio około: 2,4 ; 4,$8 ; 7,2 ; 12 ; 24$ i $48 \mu \mathrm{g}$.

5.8. Roztwór do wyznaczania współczynnika desorpcji

Do zważonej kolby pomiarowej o pojemności $10 \mathrm{ml}$ odważyć około $48 \mathrm{mg}$ akrylonitrylu, kolbę zważyć, uzupełnić do kreski roztworem acetonu 
w disiarczku węgla wg punktu 5.4. i dokładnie wymieszać. Stężenie akrylonitrylu w tak przygotowanym roztworze wynosi około $4,8 \mathrm{mg} / \mathrm{ml}$.

Roztwory wg punktów 5.5., 5.6., 5.7. i 5.8. przechowywane w chłodziarce zachowują trwałość co najmniej trzy dni.

5.9. Gazy sprężone do chromatografu Hel jako gaz nośny, wodór i powietrze do detektora o czystości według instrukcji do chromatografu.

\section{Przyrządy pomiarowe i sprzęt pomocniczy}

Stosować typowy sprzęt laboratoryjny oraz wymieniony niżej:

6.1. Chromatograf gazowy

Chromatograf gazowy $\mathrm{z}$ detektorem płomieniowo-jonizacyjnym oraz z dozownikiem umożliwiającym dzielenie próbki.

\subsection{Kolumna chromatograficzna}

Kolumna chromatograficzna umożliwiająca rozdzielenie akrylonitrylu od innych substancji występujących jednocześnie $\mathrm{w}$ badanym powietrzu, np. kolumna DB-VRX o długości $60 \mathrm{~m}$, o średnicy wewnętrznej $0,25 \mathrm{~mm} ; 1,4 \mu \mathrm{m}$.

6.3. Pompa ssąca

Pompa ssąca umożliwiająca pobieranie próbek powietrza ze stałym strumieniem objętości wg punktu 7.

6.4. Naczynka do desorpcji

Naczynka szklane, o pojemności około $3 \mathrm{ml}$ z nakrętkami i uszczelkami silikonowymi, wyposażone $\mathrm{w}$ zawory umożliwiające pobieranie roztworu bez otwierania naczynek.

6.5. Rurki pochłaniające

Gotowe rurki szklane zawierające dwie warstwy węgla aktywnego (100 mg i $50 \mathrm{mg}$ ), rozdzielone i ograniczone włóknem szklanym.

6.6. Strzykawki do cieczy

Strzykawki do cieczy o pojemności $5 \mu \mathrm{l} \div 1 \mathrm{ml}$.

\section{Pobieranie próbek powietrza}

Próbki powietrza należy pobierać zgodnie $\mathrm{z}$ zasadami podanymi w normie PN-Z-04008-7. W miejscu pobierania próbek powietrza przez rurkę pochłaniającą wg punktu 6.5. przepuścić do 241 badanego powietrza ze stałym strumieniem objętości nie większym niż $8 \mathrm{l} / \mathrm{h}$.

Pobrane próbki przechowywane w chłodziarce zachowują trwałość co najmniej przez cztery dni.

\section{Warunki pracy chromatografu}

Warunki pracy chromatografu należy dobrać tak, aby uzyskać rozdzielenie akrylonitrylu od innych substancji występujących jednocześnie $\mathrm{w}$ badanym powietrzu. W przypadku stosowania kolumny o parametrach podanych $\mathrm{w}$ punkcie 6.2. przykładowe warunki wykonania oznaczania są następujące:

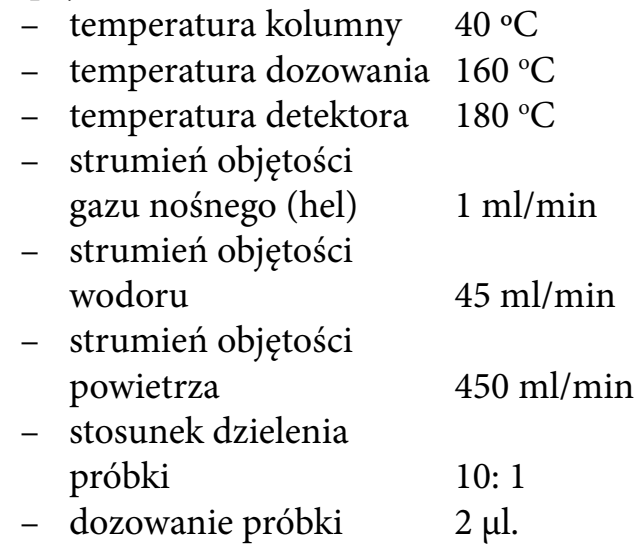

\section{Sporządzanie krzywej wzorcowej}

Do chromatografu wprowadzić po $2 \mu$ roztworów wzorcowych roboczych akrylonitrylu wg punktu 5.7. Z każdego roztworu należy wykonać dwukrotny pomiar. Odczytać powierzchnie pików według wskazań integratora i obliczyć średnią arytmetyczną. Różnica między wynikami a wartością średnią nie powinna być większa niż 5\% wartości średniej. Następnie wykreślić krzywą wzorcową, odkładając na osi odciętych zawartość akrylonitrylu w 1 mililitrze roztworów wzorcowych, w mikrogramach, a na osi rzędnych - odpowiadające im średnie powierzchnie pików.

\section{Wykonanie oznaczania}

Po pobraniu próbki powietrza przesypać oddzielnie każdą warstwę węgla aktywnego $\mathrm{z}$ rurki pochłaniającej wg punktu 6.5. do naczynek do desorpcji wg punktu 6.4. Następnie dodać strzykawką wg punktu 6.6. po $1 \mathrm{ml}$ roztworu acetonu w disiarczku węgla wg punktu 5.4., naczynka szczelnie zamknąć i pozostawić na $30 \mathrm{~min}$. Co pewien czas wstrząsnąć ich zawartością. Następnie pobrać po $2 \mu \mathrm{l}$ roztworu znad dłuższej warstwy węgla aktywnego i badać chromatograficznie w warunkach określonych $\mathrm{w}$ punkcie 8 . Z każdego roztworu należy wykonać dwukrotny pomiar. Odczytać z uzyskanych chromatogramów 
powierzchnie pików akrylonitrylu wg wskazań integratora i obliczyć średnią arytmetyczną. Różnica między wynikami a wartością średnią nie powinna być większa niż 5\% wartości średniej. Z krzywych wzorcowych odczytać zawartość akrylonitrylu $w$ badanym roztworze, $w$ mikrogramach.

W taki sam sposób wykonać oznaczanie akrylonitrylu w roztworze znad krótszej warstwy węgla aktywnego. Zawartość akrylonitrylu oznaczona w krótszej warstwie węgla aktywnego nie powinna przekraczać $10 \%$ zawartości oznaczonej w dłuższej warstwie węgla. W przeciwnym razie wynik należy traktować jako orientacyjny.

\section{Wyznaczanie współczynnika desorpcji}

Do pięciu naczynek do desorpcji wg punktu 6.4. przesypać dłuższą warstwę węgla aktywnego (100 mg) z rurek pochłaniających wg punktu 6.5. Następnie dodać po $5 \mu \mathrm{l}$ roztworu do wyznaczania współczynnika desorpcji wg punktu 5.8. W szóstym naczynku przygotować roztwór kontrolny zawierający tylko dłuższą warstwę węgla aktywnego. Naczynka szczelnie zamknąć i pozostawić do następnego dnia. Następnie dodać strzykawką wg punktu 6.6. po $1 \mathrm{ml}$ roztworu acetonu w disiarczku węgla wg punktu 5.4. Naczynka ponownie zamknąć i przeprowadzić desorpcję w ciągu $30 \mathrm{~min}$, wstrząsając co pewien czas ich zawartością. Jednocześnie wykonać oznaczanie akrylonitrylu w co najmniej trzech roztworach porównawczych przygotowanych przez dodanie do $1 \mathrm{ml}$ roztworu acetonu w disiarczku węgla wg punktu 5.4. po $5 \mu$ roztworu do wyznaczania współczynnika desorpcji wg punktu 5.8. Tak uzyskane roztwory badać chromatograficznie w warunkach określonych wg punktu 8.

Współczynnik desorpcji akrylonitrylu (d) obliczyć na podstawie wzoru:

w którym:

$$
d=\frac{P_{d}-P_{o}}{P_{p}},
$$

$P_{d}-$ średnia powierzchnia piku akrylonitrylu na chromatogramach roztworów po desorpcji,

$P_{o}$ - średnia powierzchnia piku o czasie retencji akrylonitrylu na chromatogramach roztworu kontrolnego,

$P_{p}$ - średnia powierzchnia piku akrylonitrylu na chromatogramach roztworów porównawczych.
Następnie obliczyć średnią wartość współczynnika desorpcji akrylonitrylu $(\bar{d})$ jako średnią arytmetyczną otrzymanych wartości $(d)$.

Współczynnik desorpcji należy wyznaczać dla każdej nowej partii rurek pochłaniających wg punktu 6.5.

\section{Obliczanie wyniku oznaczania}

Stężenie akrylonitrylu $(X)$ w badanym powietrzu obliczyć w miligramach na metr sześcienny na podstawie wzoru:

$$
X=\frac{\left(m_{1}+m_{2}\right)}{V \cdot \bar{d}},
$$

w którym:

$m_{1}$ - zawartość akrylonitrylu $\mathrm{w}$ roztworze znad dłuższej warstwy węgla aktywnego, odczytana z krzywej wzorcowej, w mikrogramach,

$m_{2}-$ zawartość akrylonitrylu $\mathrm{w}$ roztworze znad krótszej warstwy węgla aktywnego, odczytana z krzywej wzorcowej, w mikrogramach,

$V$ - objętość powietrza przepuszczonego przez rurkę pochłaniającą, w litrach,

$\bar{d}$ - średnia wartość współczynnika desorpcji wyznaczanego wg punktu 11. 
